\title{
Daily Activity of Ground Rivers Cycle
}

\author{
Salman M. Al-Kasimi \\ The Research Institute of Umm-UI-Qura University, Makkah, KSA \\ Email: salmanalkasimi@yahoo.com
}

Received 20 October 2014; revised 21 November 2014; accepted 10 December 2014

Copyright (C) 2014 by author and Scientific Research Publishing Inc.

This work is licensed under the Creative Commons Attribution International License (CC BY).

http://creativecommons.org/licenses/by/4.0/

c) (i) Open Access

\begin{abstract}
This article describes a 24-hour daily activity of ground water cycle. It first proves the existence of vapour up-flux using a custom-made reflective carpet. At high grounds of equatorial altitudes above 1500 meter (less than that for other latitudes), water vapour is thought to be condensed forming fresh water within mountains. An evidence of this was found in several sites in Saudi Arabia, where fresh water down-streams from these mountains and pops-out of mountain sides or up from ground surface. Photos of such streams are presented. Another evidence of these rivers is presented in photos of green coastal regions in Saudi Arabia. The paper urges researchers to make concise annual water-budget studies for major known rivers in the world, to prove that rainfall in the basin of each of them runs severely short to explain the annual river flow quantity.
\end{abstract}

\section{Keywords}

Fresh Water Cycle, Mountain-Water, Ocean-Land Stream, Water-Fingerprint, Isotopes of Hydrogen and Oxygen

\section{Introduction}

Water has so many active mechanisms underground, all interacting. Ground Rivers are distinctive part of groundwater. They follow one well-defined mechanism. This article describes that particular mechanism and its activity. Although this article is peculiar, the water issue is so important to life, that not a single scientist opinion could be ignored. The author-work over the issue extends for 18 years. The popularity of the idea will grow by engaging global minds to dialog about it and rectify any ambiguities.

Ground rivers are naturally formed rivers of fresh water that are totally cycling underground [1]. They are formed from sea deep water that continuously penetrates land through soil voids by the enormous hydraulic pressure forming the water table, see Figure 1. With temperature gradient of: 25 - 30 degrees $\mathrm{C}$ per kilometer depth, vaporization occurs at 3 - $4 \mathrm{~km}$ below sea level, leaving salts behind. The vapour ascends up through soil voids and at low grounds it escapes land to air and joins clouds [2]. Figure 1 also shows one of the most hidden 
sea (and ocean) circulation current, the sea-land current. The vapour thermal mechanics over centuries of time crack and grind low ground geological formations creating sand deserts, although the vapour flux passing through can help turning it green [3].

Figure 2 shows a custom-made square reflective carpet (designed and manufactured by the author), $50 \mathrm{~cm}$ aside, made of small adjacent PVC plastic cones. The carpet was placed in plant-free dry desert area for five months in 2001. Without rain or irrigation, it managed to capture and condense enough ground vapours to bring to life naturally buried seeds underneath it. The green area is about $10 \%$ of the carpet area. It is expected that if seeds were put before placing this carpet, then much wider area would become green.

The vapour flux coming up at low ground surface, in regions at equatorial belt, can also condense when facing muddy soil or cold weather. Example of muddy soil condensed vapour explains natural forest formations at places where rain-falls run short to explain, and it also explains the survival of desert oasis. Example of cold weather condensed vapour explains fog and low cloud formations at such places.

If not captured, the vapour flux coming up at low ground surface, escapes off land through soil voids, and joins sky clouds, un-noticed. This joining has a very active role in cloud lightening as thought by the author. In Saudi Arabia, clouds coming past the desert are noticed to be dark and full of charge, with fierce lightening; unlike clouds past the sea.

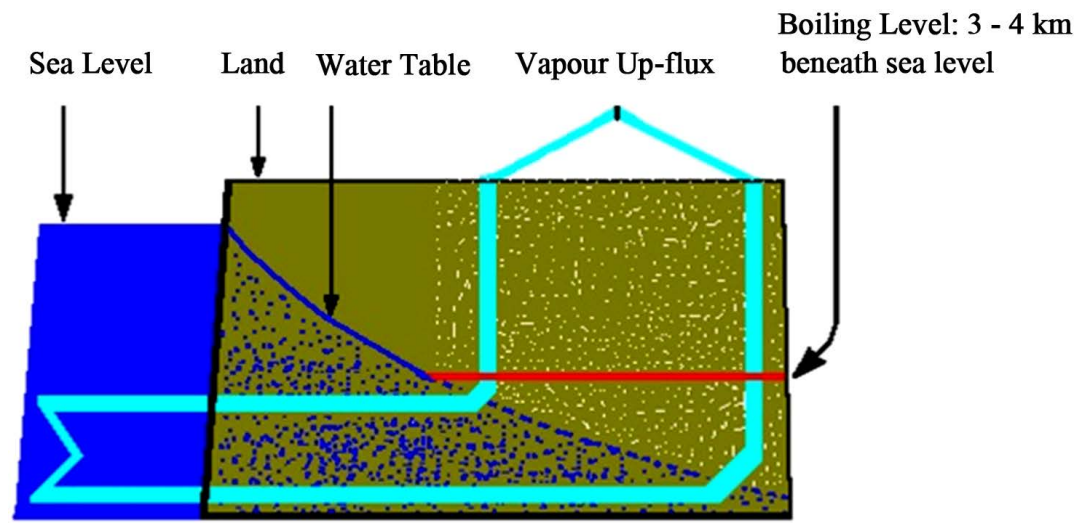

Figure 1. Diffused water from deep ocean into land soil evaporating beneath 3 - 4 $\mathrm{km}$ from sea level.

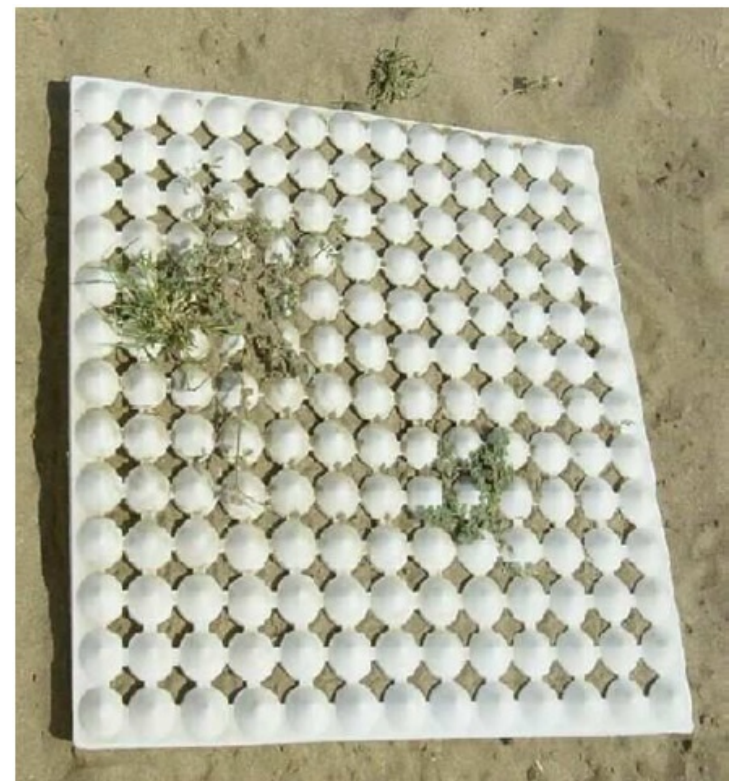

Figure 2. Reflective carpet capturing vapour up-flux and turning the desert green in 5 months. 


\section{Scenarios for Naturally-Trapped Vapour-Flux}

The vapour up-going flux, that was unable to escape to atmosphere, can face various scenarios, depending on the height of ground surface, ground geology and layer properties. One scenario that can be called the compressed-vapour-pocket scenario, happens when ground surface is less than 300 meter above sea level with conservative geology and non-porous layers. Here, the vapour is trapped directly above where it has vapourized, forming a cooking pot. Crude Oil is a very likely product of such scenario.

Another scenario, which can be called the foggy scenario, happens when ground surface is less than 300 meter above sea level with conservative geology and porous layers. Here, the vapour trapped directly above, where it has vapourized, manage to escape from the sides to the atmosphere, in such a quantity that it forms fog at the surface of that region.

A third scenario, can be called the warming scenario, happens when ground surface is more than 2000 meter above sea level with conservative geology and non-porous layers. Here, the vapour trapped directly above, where it has vapourized, gets colder and colder till it condenses to drops of liquid fresh water and fall as water droplets; re-evapourate, re-condense and re-fall; and so on, in an endless cycle; resulting in heat exchange that warms up the ground.

\section{The Ground River Scenario}

The scenarios of the vapour behavior are endless. However, the most important one is the river scenario. This scenario happens when ground surface is more than 2000 meter above sea level with wide spreading conservative geology and porous layers. Here again, the vapour gets colder and colder till it condenses to drops of liquid fresh water. Due to porosity, these droplets manage to move, making ground-rivers, reservoirs and tunnels. They flow back to the sea. In certain conditions, some ground rivers flowing to the sea manage to hold tact, forming fresh-water lakes floating on sea, see Figure 3.

This hidden ground water-cycle is very much responsible for the formation of ground caves over centuries. Some known, and most unknown, these caves often end with fresh water flow or reservoir.

Figure 4 shows an opening to a natural ground duct in Hanakyyia of Saudi Arabia, $1500 \mathrm{~m}$ above sea level at: $\left(25.46087^{\circ} \mathrm{N}, 39.96142^{\circ} \mathrm{E}\right)$. Hanakyyia is a village between Madinah and Qaseem of Saudi Arabia. The tunnel is known to branch to a network of ground tunnels that lead to flowing ground fresh-water, according to locals in Nakheel village near Hanakyyia village north of Saudi Arabia (captured by: A. R. H. Mohammadi for Madina Newspaper in: 2001) [4].

\section{Findings, Conclusions and Recommendations}

The hidden ground water cycle interferes quite well with the known rainfall water cycle that develops from solar energy evaporating sea surface water (not deep sea water), making the vapour to ascend into atmosphere cold heights, where it condenses to water and ice droplets that descend back to earth as snow, rain, and ice hails. However, this interference (as much illusive and deceptive it is), is quite detectable. A ground river is driven by

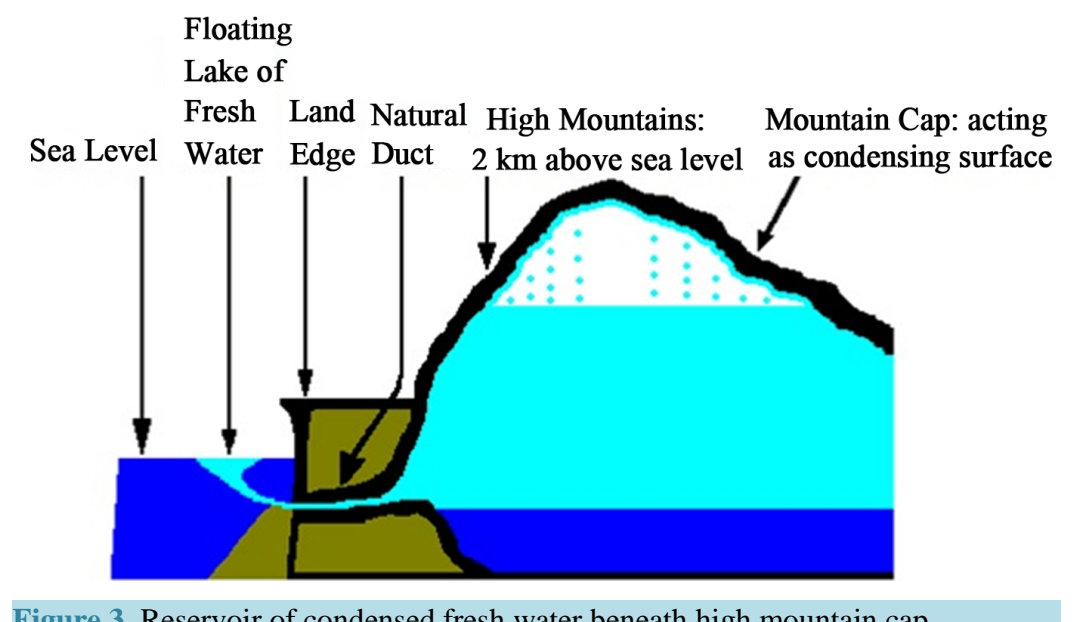

Figure 3. Reservoir of condensed fresh water beneath high mountain cap. 


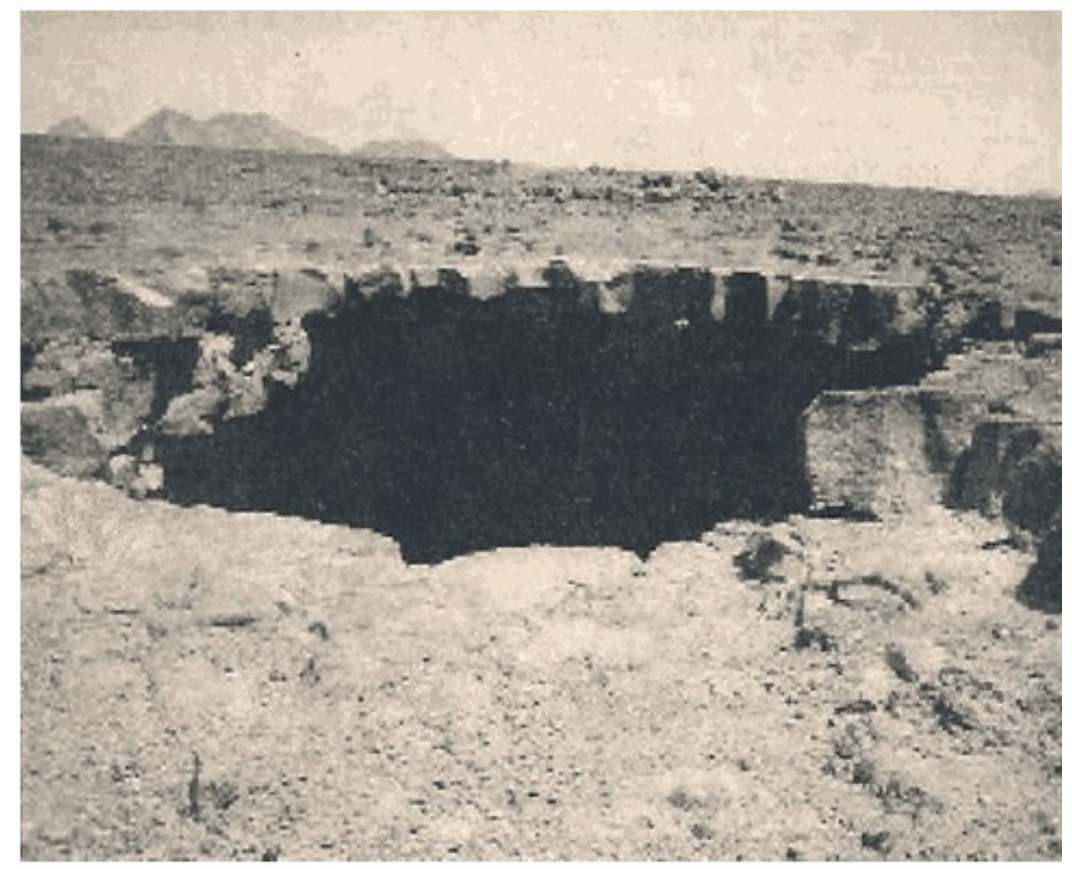

Figure 4. An opening of natural ground duct leading to water at Hanakyia of Saudi Arabia.

a 24-hour daily mechanism. It is strongly attached to high mountains (2 $\mathrm{km}$ above sea level at equatorial latitudes and less at higher latitudes). Its flow rate is proportional to the spreadth of the mountain. It may, under certain conditions, pop up to earth surface, flow for a distance, and then sink again. This causes the evolution of: "dis-continued" rivers that flow all the time, but are not reaching to the sea. They rather sink back to ground, or get consumed, as seen in Figure 5.

Here is shown a green cover at popped ground-river called: Najl of Shaqqa Yamanyyia, that sprang to surface at: $\left(20.11115^{\circ} \mathrm{N}, 40.91944^{\circ} \mathrm{E}\right)$. It flew at start at about: $40 \mathrm{~m}^{3} / \mathrm{min}$, ran for more than $30 \mathrm{~km}$, then sank at: $\left(19.90283^{\circ} \mathrm{N}, 40.72438^{\circ} \mathrm{E}\right)$, making a lake of fresh water, $15 \mathrm{~km}$ off green covered shore, at Red Sea In Saudi Arabia. The view was captured in 2001 by a research team formed by the author. Sadly, a wild flood several years later, dumped rocks and soil, $5 \mathrm{~m}$ high above the springing location, after which the Najl shrank both in flow rate and in running length, digging its own alternative path.

Figure 6 shows another typical ground-water popping in mountains. It is called "Thee-Ain” spring flowing at about: $1 \mathrm{~m}^{3} / \mathrm{min}$ off mountain cavity, $750 \mathrm{~m}$ above sea level at: $\left(19.92950^{\circ} \mathrm{N}, 41.44301^{\circ} \mathrm{E}\right)$, which according to locals never dries in draught seasons and keeps supplying fresh water to farms in "Thee-Ain" village near "Baha" city west of Saudi Arabia. The view was captured in 2001 by a research team formed by the author.

The above-mentioned two cases of Figure 5 and Figure 6, are examples for "dis-continued" popped flows. However, under other certain conditions, fresh ground water may pop up to earth surface, and flow in conjunction with a known river back to sea, without spatial dis-continuity. Water budget calculations, will reveal such interference. Regular non-stop flow of surface rivers, suggests that there are some ground rivers popping out to the stream of known surface rivers, forming their back-bone. Dispersed in location and time, the rain feed for rivers, stops short to explain such regularity.

Some other ground rivers, particularly the wild ones, can be detected by the existence of peaky mountains all along their hidden way to sea. For them, the sea itself shows that through two signs: sea tongue and green shore. The sea tongue is formed by the constant removal of underground soil particles, which over centuries of time lower the shore level, hence sea water re-fill. On the other hand, the dumped fresh water makes the shore less saline, hence allowing green cover to develop, as seen in Figure 7 and Figure 8.

Figure 7 is a captured photo in 2001 by a research team formed by the author. It shows the green cover at Red Sea shore of: “Qahma” $\left(18.00452^{\circ} \mathrm{N}, 41.67517^{\circ} \mathrm{E}\right)$ in Saudi Arabia.

Figure 8 is a captured photo in 2001 by a research team formed by the author. It shows the green cover at Red Sea shore of: "Omloj” $\left(25.08172^{\circ} \mathrm{N}, 37.25857^{\circ} \mathrm{E}\right)$ in Saudi Arabia. 


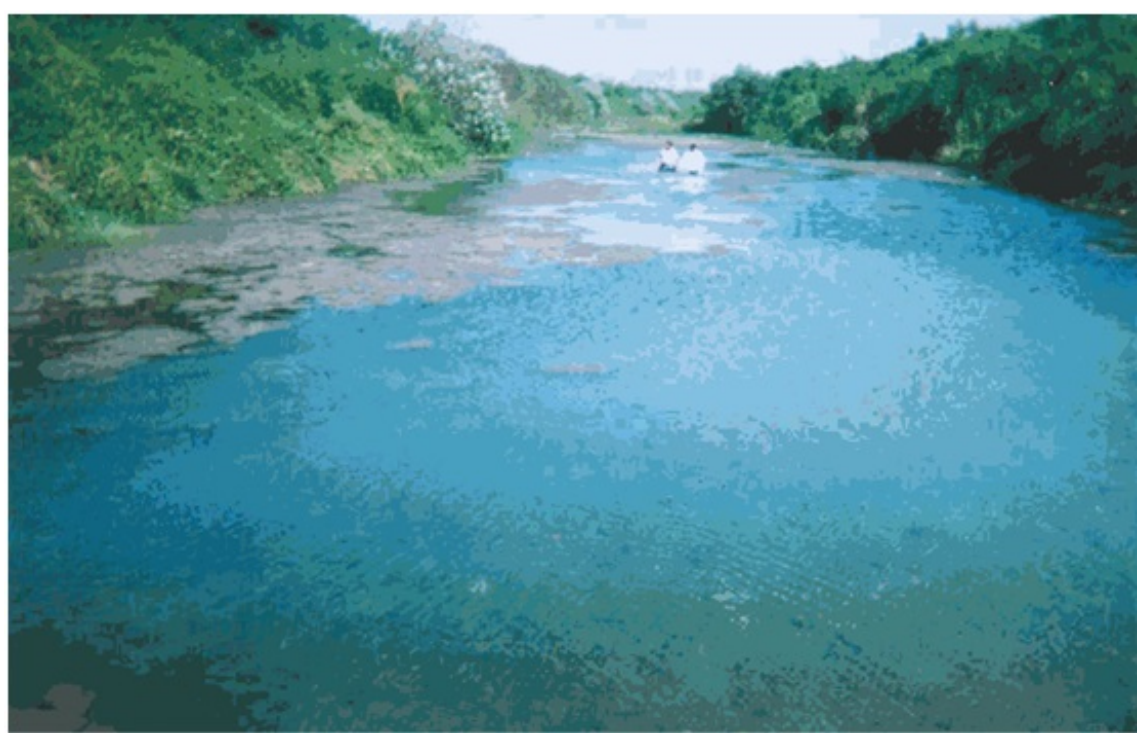

Figure 5. Popped ground-river in Shaqqa Yamanyyia of Saudi Arabia.

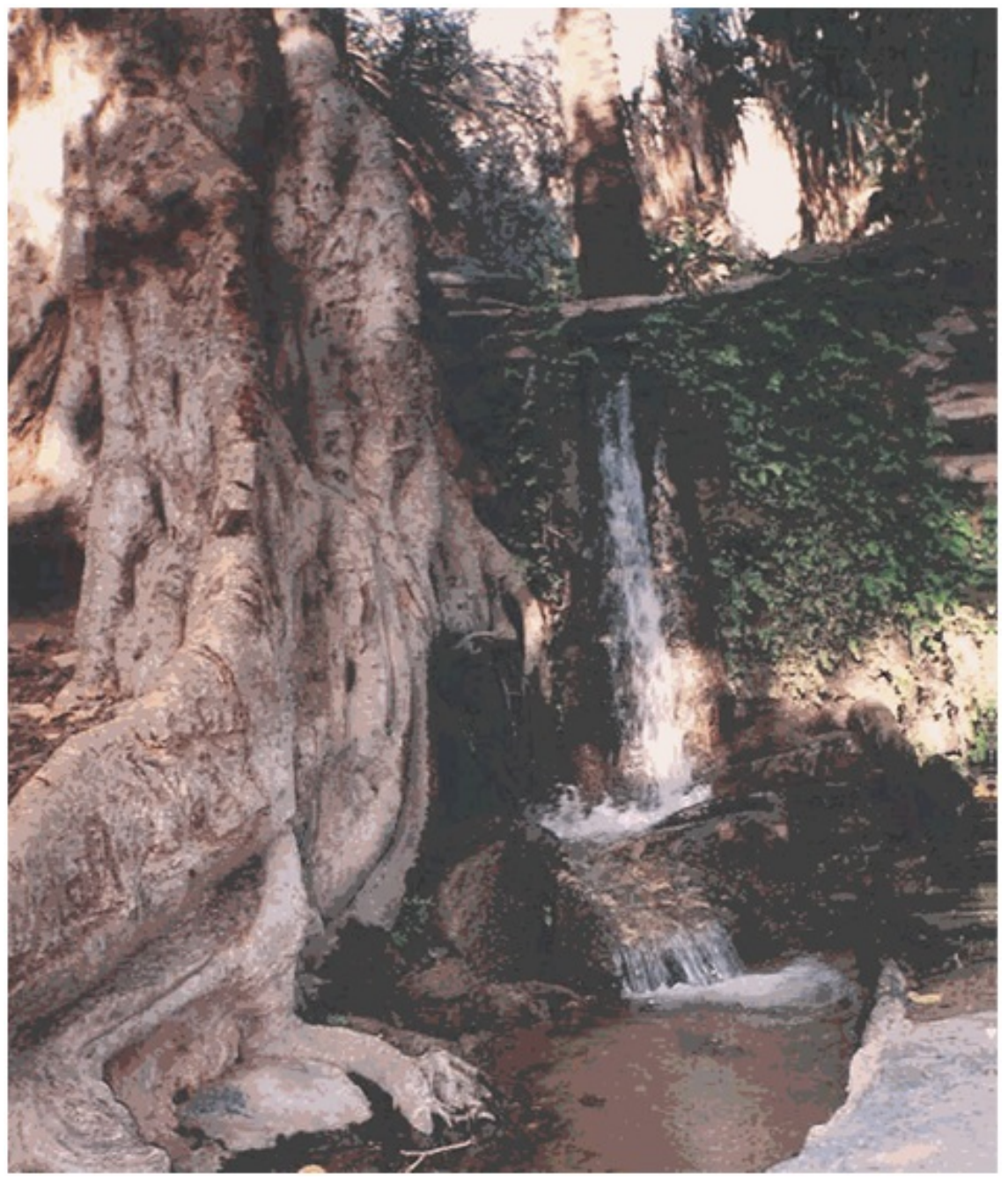

Figure 6. Popped water spring in Thee-Ain of Saudi Arabia. 


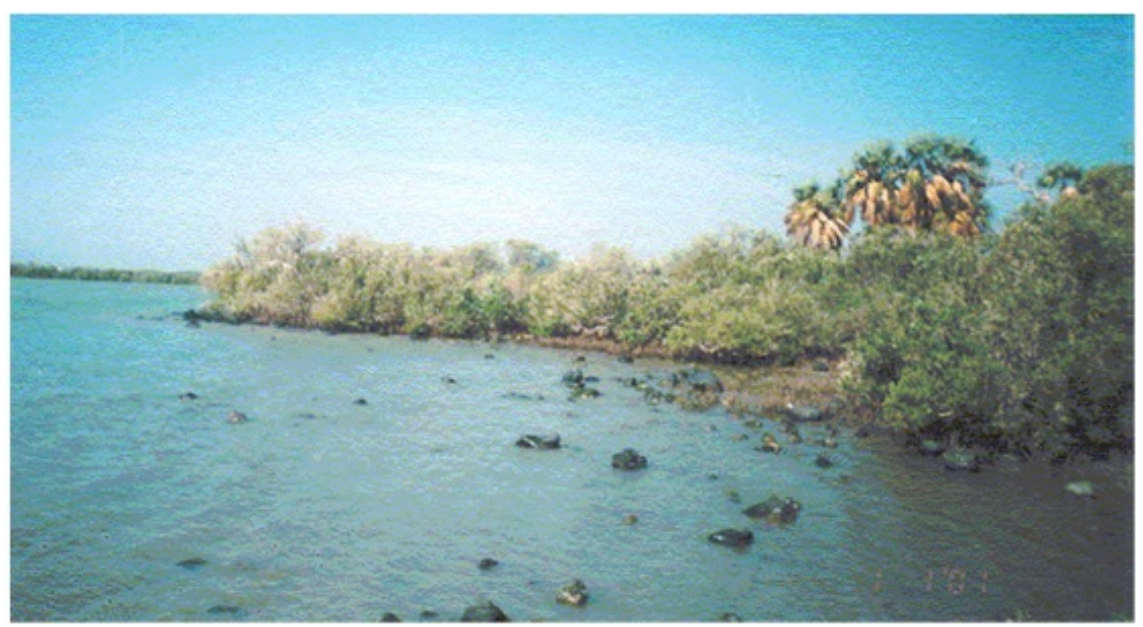

Figure 7. Green cover at sea side in Qahma of Saudi Arabia.

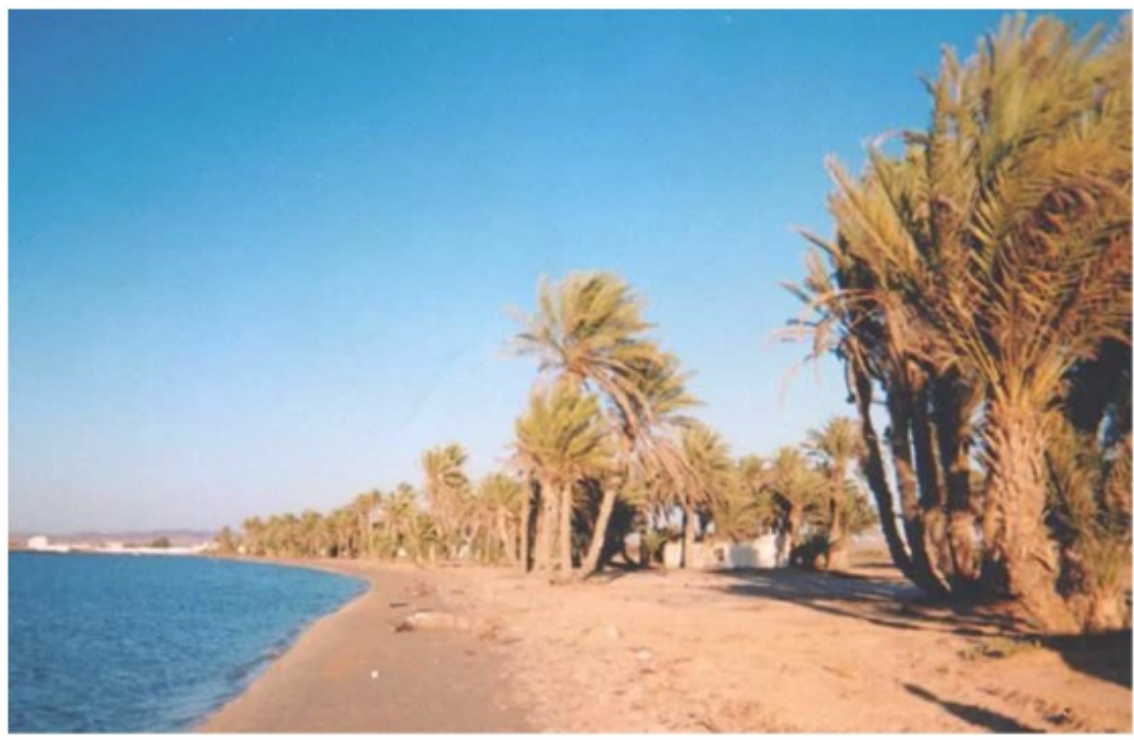

Figure 8. Green cover at sea side in Omloj of Saudi Arabia.

The mountain-water and rain-water can be distinguished by testing. In mountain-water, hydrogen and oxygen isotopes exist in much abundance than in rain-water. This is because the former comes from deep sea water, while the latter from surface water. This makes the two types of water differ in radio-activity and specific gravity as thought by the author.

It is thought that the dissolved salts in the former are mostly sulfides since Sulfur is abundant beneath earth surface, while in the latter they are oxides due to $\mathrm{O}_{2}$ abundance in atmosphere. Ph-level and types of bacteria differ accordingly.

It is worth to emphasize, that the ground river cycle is a 24-hour continuous daily mechanism. On the other hand, the rainfall water cycle is a discontinuous mechanism that runs "on and off" at dispersed times and locations. Logically speaking, it is reasonable to attach the sustenance of known rivers to the ground cycle.

Testing any water specimen using elemental and isotopical spectroscopy, particularly for Hydrogen and Oxygen isotopes, will enable oceanography specialists to assure the origin of water, whether it is coming from surface or deep sea-levels (below $3 \mathrm{~km}$ ).

\section{References}

[1] Al-Kasimi, S.M. (1998) Underground Rain \& Rivers: Theory of Existence and Means of Detection. The Engineer 
(Riyadh of Saudi Arabia), 9, 57-59.

[2] Al-Kasimi, S.M. (2002) Existence of Ground Vapour-Flux Up-Flow: Proof \& Utilization in Planting the Desert Using Reflective Carpet. Proceedings of the Saudi Sixth Engineering Conference, Dahran of Saudi Arabia, 3, 105-119.

[3] Al-Kasimi, S.M. (2003) Evolution of Sand and Dune Creep-Stopping by Planting the Desert. Proceedings of the International Conference on Dune-Creep into Rail Roads and Cure Methods, Dammam of Saudi Arabia by Arabian Union for Rail Roads \& Saudi Rail.

[4] Al-Mohammadi, A.R.H. (2001) Hanakyyia Tunnels: The Lost Paradise. Report in Arabic "Madina” Newspaper in Saudi Arabia. 
Scientific Research Publishing (SCIRP) is one of the largest Open Access journal publishers. It is currently publishing more than 200 open access, online, peer-reviewed journals covering a wide range of academic disciplines. SCIRP serves the worldwide academic communities and contributes to the progress and application of science with its publication.

Other selected journals from SCIRP are listed as below. Submit your manuscript to us via either submit@scirp.org or Online Submission Portal.
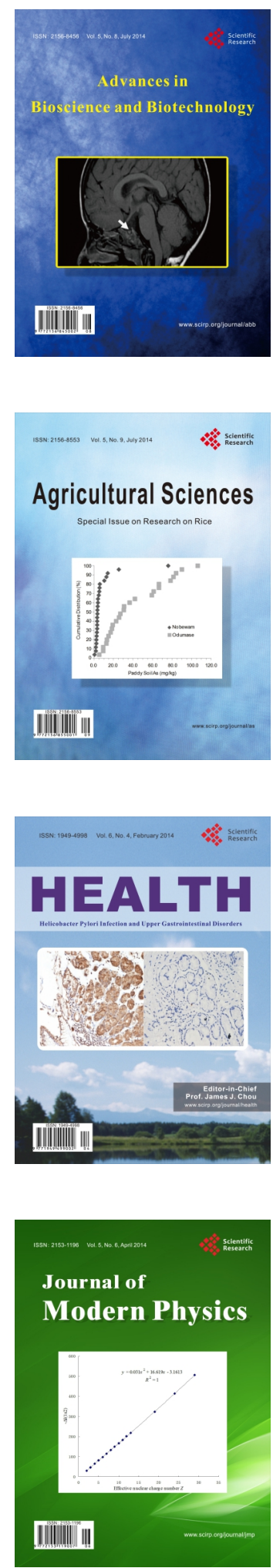
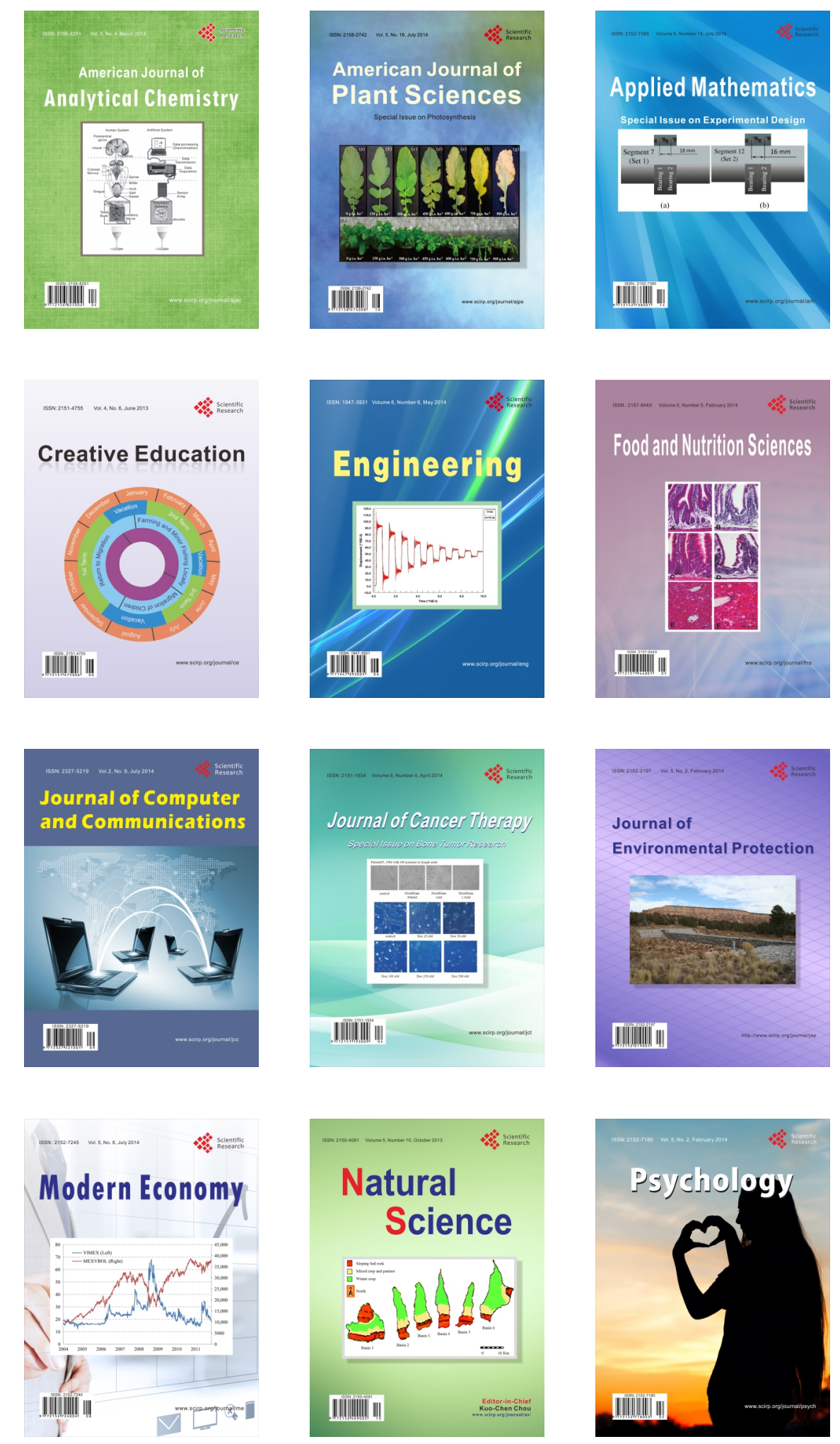